\title{
POSTNATAL PLASMA SHIFT IN PREMATURE INFANTS
}

\author{
BY \\ A. C. L. CLARK and DOUGLAS GAIRDNER \\ From the Department of Medicine, University of Cambridge and the Cambridge Maternity Hospital
}

(RECEIVED FOR PUBLICATION OCTOBER 28, 1959)

In the normal infant birth is usually followed by a substantial rise in the concentration of haemoglobin $(\mathrm{Hb})$ and in the packed cell volume (PCV) of the blood, while the concentration of plasma protein tends to rise only slightly (Gairdner, Marks, Roscoe and Brettell, 1958). From these facts we have inferred that immediately following birth there is a loss from the vascular compartment of a large fraction, up to a quarter or more, of the circulating plasma.

We do not know the fate of the plasma lost from the vascular compartment, but we have suggested that the major changes which take place in the pulmonary circulation at birth might be expected to favour a shift of fluid from the circulation at this site. If so, then shift of plasma into the interstitial spaces of the lung might play a part in the pulmonary failure which so often overtakes the premature infant in the first few hours or days after birth. For this reason, we have extended our observations to premature infants to determine whether there is any relationship between the postnatal haemoconcentration effect and the development of pulmonary symptoms.

\section{Material and Methods}

Cord blood was obtained from 24 infants with birth weight of less than 2,500 g., of whom 22 were born vaginally and two by caesarean section. Maternal toxaemia was present in six cases. Neither the method of delivery, nor the presence of maternal toxaemia appeared to affect the results, and they have not been separately analysed here.

The cord was always clamped as soon as conveniently possible, both in vaginal and in caesarean deliveries. A blood sample was taken by puncture of the umbilical vein between placenta and clamp. Subsequent specimens were taken by insertion of a polyvinyl cannula (internal diameter $1.0 \mathrm{~mm}$.) into the umbilical vein, or in a few cases by femoral vein puncture. Samples were taken into siliconized bottles containing ethylenediamine tetra-acetate as anticoagulant.

$\mathrm{Hb}$ concentration and PCV were estimated as described previously (Marks, Gairdner and Roscoe, 1955), in duplicate in most cases. Plasma protein concentration was estimated by the biuret method using $0.2 \mathrm{ml}$. plasma. The estimations required less than $2 \mathrm{ml}$. blood.

The infants were closely observed for signs of respiratory distress; those commonly observed were rapid moaning respirations, often with rib recession. Nine infants showed such signs and six of these recovered.

Three infants died at 20,22 and 32 hours; all showed respiratory distress by five hours or earlier. At necropsy the lungs showed the picture of secondary atelectasis with hyaline membrane in all three cases, together with massive intra-alveolar haemorrhage in one case, and broncho-pneumonia in another.

\section{Results}

Change in $\mathbf{H b}$ Concentration a Few Hours after Birth. A second specimen of blood was obtained from 24 premature infants at some time between one and eight hours after birth, in most instances about two hours after birth. The mean $\mathrm{Hb}$ was $17.9 \mathrm{~g}$./ $100 \mathrm{ml}$. (S.D. $2 \cdot 0$ ) in cord blood and $19 \cdot 4 \mathrm{~g} . / 100 \mathrm{ml}$. (S.D. 2.3) at one to eight hours. The difference of $1.5 \mathrm{~g} . / 100 \mathrm{ml}$. is just significant $(\mathrm{P}=0.05)$.

Fig. 1 shows the change in the $\mathrm{Hb}$ concentration shortly after birth related to the initial cord $\mathrm{Hb}$.

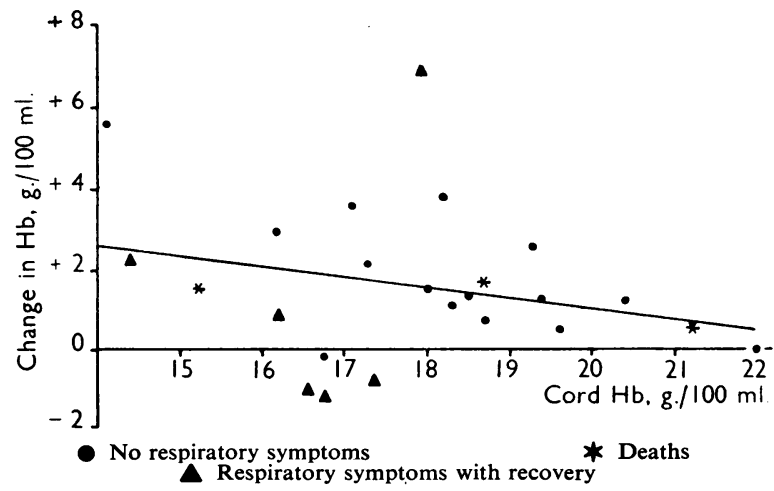

FIG. 1.-Relation of change in $\mathrm{Hb}$ level 1-8 hours after birth to initial (cord) $\mathrm{Hb}$ level, in 24 premature infants, of whom nine showed respiratory distress symptoms with three deaths. A regression line has been drawn, but the correlation coefficient is not significant. 
There is some tendency for the change to be larger when the cord $\mathrm{Hb}$ level lies towards the lower side of normal, but the correlation is not significant (correlation coefficient $-0 \cdot 23$ ).

The degree of postnatal haemoconcentration observed in the nine infants who subsequently developed respiratory distress, including the three who died, was similar to that in the remainder of the group.

Change in Mean Corpuscular $\mathrm{Hb}$ Concentration (MCHC) a Few Hours after Birth. $\mathrm{Hb}$ and PCV were estimated in cord blood and again in a second specimen taken between one and eight hours after birth, and Fig. 2 shows the percentage change in PCV compared with the percentage change in $\mathrm{Hb}$ concentration. Had the $\mathrm{Hb}$ concentration and

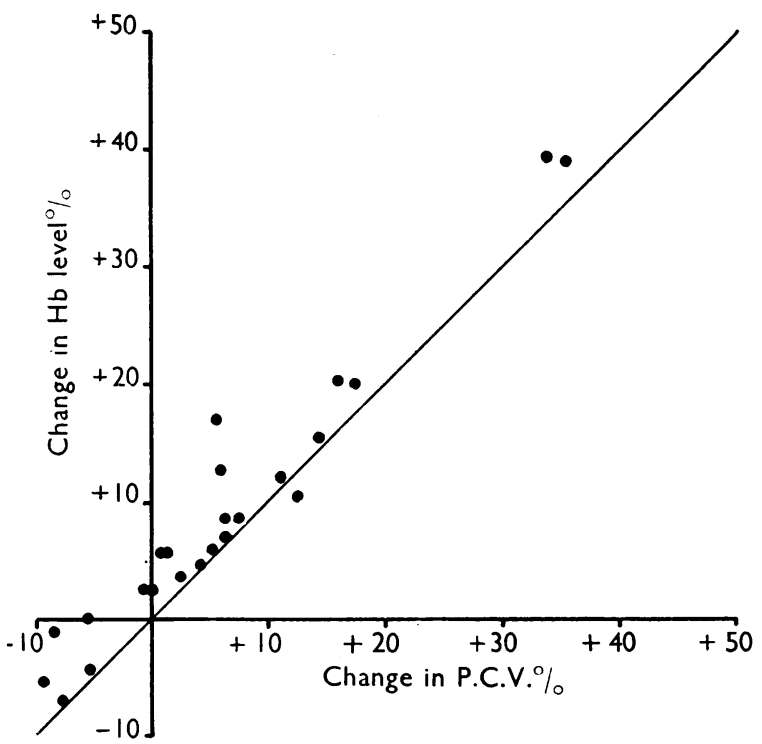

FIG. 2.-Relation of change in Hb level 1-8 hours after birth to change in packed cell volume, 24 cases. The line bisects the axes. Note that the change in $\mathrm{Hb}$ exceeds the change in PCV.

PCV moved strictly in parallel, the points would have been grouped about the straight line bisecting the axes. In fact, all but one point fall above this line showing that the rise in $\mathrm{Hb}$ concentration is proportionately greater than the rise in PCV. Since the ratio $\frac{\mathrm{Hb} \text { concentration }}{\mathrm{PCV}}$ defines the mean corpuscular $\mathrm{Hb}$ concentration (MCHC), these results indicate a postnatal rise in $\mathrm{MCHC}$.

The mean MCHC of cord blood in the 24 cases was $32.3 \%$ and in blood at one to eight hours, $33.3 \%$, a postnatal rise of $3 \%$.
Change in Plasma Protein Concentration a Few Hours after Birth. Plasma protein concentration could not be measured in all cases, because findings were often invalidated by haemolysis, even a trace of which renders inaccurate measurements of plasma protein. We have not discovered means of avoiding this annoying tendency for blood samples taken in the early neonatal period to undergo haemolysis.

In the nine cases where full data were available, no consistent change in plasma protein concentration was found. The mean concentration in cord blood was $5 \cdot 3 \mathrm{~g}$. and between one and eight hours 5.2 g. $/ 100 \mathrm{ml}$. Four subjects showed decreases of up to $9 \%$, one showed no change and four showed increases of up to $12 \%$.

\section{Discussion}

The Postnatal Haemoconcentration Effect and its Relation to Pulmonary Failure in Premature Infants. Comparing the $\mathrm{Hb}$ concentration in blood at birth (cord blood) with that after birth (1-8 hours), our findings in premature infants show essentially the same changes in haemoconcentration as were previously found in normal infants (see Table).

\section{TABLE}

POSTNATAL CHANGES IN BLOOD IN NORMAL AND PREMATURE INFANTS

\begin{tabular}{|c|c|c|c|c|c|}
\hline & & $\begin{array}{l}\text { No. of } \\
\text { Cases }\end{array}$ & $\begin{array}{c}\text { Cord } \\
\text { Blood }\end{array}$ & $\begin{array}{l}\text { At } 1-8 \\
\text { Hours }\end{array}$ & $\begin{array}{l}\text { Postnatal } \\
\text { Change \% }\end{array}$ \\
\hline Normal & $\left\{\begin{array}{l}\mathrm{Hb}, \mathrm{g} . \% \\
\text { MCHC, \% } \\
\text { Plasma protein, } \%\end{array}\right.$ & $\begin{array}{r}92 \\
92 \\
17\end{array}$ & $\begin{array}{r}16 \cdot 6 \\
32 \cdot 3 \\
6 \cdot 5\end{array}$ & $\begin{array}{r}19 \cdot 1 \\
33 \cdot 6 \\
7 \cdot 0\end{array}$ & $\begin{array}{l}+16 \\
+4 \\
+8\end{array}$ \\
\hline Premature & $\left\{\begin{array}{l}\mathrm{Hb}, \mathrm{g} . \% \\
\text { MCHC, \% } \\
\text { Plasma protein, } \%\end{array}\right.$ & $\begin{array}{r}24 \\
24 \\
9\end{array}$ & $\begin{array}{r}17 \cdot 9 \\
32 \cdot 3 \\
5 \cdot 3\end{array}$ & $\begin{array}{r}19 \cdot 4 \\
33 \cdot 3 \\
5 \cdot 2\end{array}$ & $\begin{array}{r}+9 \\
+3 \\
-2\end{array}$ \\
\hline
\end{tabular}

In our earlier paper we considered in turn the possible causes of the postnatal rise in $\mathrm{Hb}$ concentration as seen in normal infants, and arrived at the conclusion that it results from a reduction in plasma volume (Gairdner et al., 1958). The same arguments and the same conclusion must apply equally to the present findings in premature infants.

The fact that while the concentration of $\mathrm{Hb}$ in the premature rises by an average of $9 \%$, the concentration of plasma protein remains virtually unchanged, implies that the fluid leaving the vascular compartment contains about the same concentration of protein as does plasma. Thus we conclude that in premature infants as in normal infants, birth is often immediately followed by the loss of an appreciable fraction of the plasma from the vascular compartment.

As an instance of the magnitude the plasma shift may attain, details of one case are given. A 35-week 
premature infant with a birth weight of $2,240 \mathrm{~g}$. had a cord blood $\mathrm{Hb}$ level of $18.1 \mathrm{~g} . / 100 \mathrm{ml}$. and a PCV of $56 \%$. At 8 hours the $\mathrm{Hb}$ level had risen to $25 \cdot 2 \mathrm{~g}$. and the PCV to $75 \%$. It was formerly shown (Gairdner et al., 1958) that the ratio

$$
\text { Plasma volume at birth }
$$

is given by

$$
\text { Plasma volume after birth }
$$

$$
\frac{\mathrm{Hb}_{2}\left(1-0.83 \mathrm{PCV}_{1}\right)}{\mathrm{Hb}_{1}\left(1-0.83 \mathrm{PCV}_{2}\right)}
$$

where the $\mathrm{Hb}$ level and the PCV are $\mathrm{Hb}_{1}, \mathrm{PCV}_{1}$ at birth and $\mathrm{Hb}_{2}, \mathrm{PCV}_{2}$ after birth. Inserting in this expression the values in our case, the ratio

$$
\frac{\text { Plasma volume at birth }}{\text { Plasma volume after birth }}=\frac{1 \cdot 98}{1}
$$

so that in this infant the plasma volume after birth was reduced by almost $50 \%$.

In this series the magnitude of the postnatal plasma shift bears no relation to the development of respiratory distress (Fig. 1), so that the present study has provided no supporting evidence for the suggestion that plasma shift, if taking place mainly in the lungs, might cause pulmonary oedema and so lead to respiratory symptoms.

The postnatal rise of $3 \%$ in the $\mathrm{MCHC}$ is close to the figure found for normal infants, and implies that birth is followed by a shift of fluid from the red cells. The possible causes of this effect also have been discussed in our earlier paper.

\section{Summary}

In premature infants, as in normal infants, birth is frequently followed by a rapid rise in the $\mathrm{Hb}$ concentration, and in the packed cell volume of venous blood, while the mean corpuscular $\mathrm{Hb}$ concentration of the red cells increases.

The cause of these changes is considered to be a considerable loss of plasma from the vascular compartment, and a small shift of fluid from the red cells.

The site at which the plasma leaves the vascular compartment remains undecided. It was suggested that the shift might take place particularly from the pulmonary circulation and so contribute to the development of pulmonary oedema and respiratory failure in the premature infant, but the development of respiratory distress in the premature infants studied could not be shown to be related to the magnitude of the plasma shift.

One of us (A.C.L.C.) was in receipt of a grant from the Elisabeth Storey Fund.

\section{REFERENCES}

Gairdner, D., Marks, J., Roscoe, J. D. and Brettell, R. O. (1958) The fluid shift from the vascular compartment immediately after birth. Arch. Dis. Childh., 33, 489.

Marks, J., Gairdner, D. and Roscoe, J. D. (1955). Blood formation in infancy. Part III, Cord blood. Ibid., 30, 117. 